\title{
Correction to: Evaluating the structural reform of outpatient psychotherapy in Germany (ES-RiP trial) - a qualitative study of provider perspectives
}

\author{
Regina Poß-Doering ${ }^{1 *}$, Martin Hegelow², Milena Borchers², Mechthild Hartmann², Johannes Kruse ${ }^{3,4}$, \\ Hanna Kampling ${ }^{3}$, Gereon Heuft ${ }^{5}$, Carsten Spitzer ${ }^{6}$, Beate Wild ${ }^{2}$, Joachim Szecsenyi ${ }^{1}$ and \\ Hans-Christoph Friederich ${ }^{2}$
}

Correction to: BMC Health Serv Res 21, 1204 (2021)

https://doi.org/10.1186/s12913-021-07220-7

Following publication of the original article [1], the authors identified an error in the author names of all the authors. The given name and family name were erroneously transposed.

The author group has been updated above and the original article [1] has been corrected.
Published online: 02 December 2021

\section{Reference}

1. Poß-Doering, et al. Evaluating the structural reform of outpatient psychotherapy in Germany (ES-RiP trial) - a qualitative study of provider perspectives. BMC Health Serv Res. 2021;21:1204. https://doi.org/10. 1186/s12913-021-07220-7.

\begin{abstract}
Author details
${ }^{1}$ Department. of General Practice and Health Services Research, University Hospital Heidelberg, Im Neuenheimer Feld 130.3, 69120 Heidelberg, Germany. ${ }^{2}$ Department of General Internal Medicine and Psychosomatics, University Hospital Heidelberg, Im Neuenheimer Feld 410, Heidelberg, Germany. ${ }^{3}$ Department of Psychosomatic Medicine and Psychotherapy, Medical Center of the Justus-Liebig-University, Friedrichstraße 33, 35392 Giessen, Germany. ${ }^{4}$ Department of Psychosomatic Medicine and Psychotherapy, Medical Center of the Philipps University Marburg, Baldingerstraße, 35043 Marburg, Germany. ${ }^{5}$ University Hospital Muenster, Section Psychosomatic Medicine and Psychotherapy, Albert-Schweitzer-Campus 1 (Geb. A9), 48149 Münster, Germany. ${ }^{6}$ University Medicine Rostock, Clinic for Psychosomatic Medicine and Psychotherapy, Gehlsheimer Str. 20, 18147 Rostock, Germany.
\end{abstract}

The original article can be found online at https://doi.org/10.1186/s12913021-07220-7.

\footnotetext{
*Correspondence: regina.poss-doering@med.uni-heidelberg.de

1 Department. of General Practice and Health Services Research, University Hospital Heidelberg, Im Neuenheimer Feld 130.3, 69120 Heidelberg, Germany

Full list of author information is available at the end of the article
}

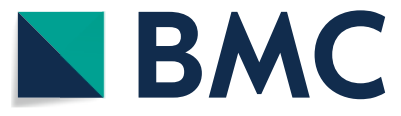

(C) The Author(s) 2021. Open Access This article is licensed under a Creative Commons Attribution 4.0 International License, which permits use, sharing, adaptation, distribution and reproduction in any medium or format, as long as you give appropriate credit to the original author(s) and the source, provide a link to the Creative Commons licence, and indicate if changes were made. The images or other third party material in this article are included in the article's Creative Commons licence, unless indicated otherwise in a credit line to the material. If material is not included in the article's Creative Commons licence and your intended use is not permitted by statutory regulation or exceeds the permitted use, you will need to obtain permission directly from the copyright holder. To view a copy of this licence, visit http://creativecommons.org/licenses/by/4.0/. The Creative Commons Public Domain Dedication waiver (http://creativeco mmons.org/publicdomain/zero/1.0/) applies to the data made available in this article, unless otherwise stated in a credit line to the data. 